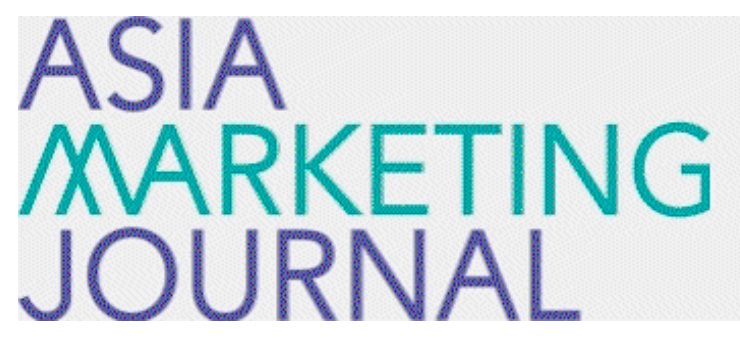

ASIA MARKETING JOURNAL

Volume 4 | Issue 3

Article 5

$9-1-2002$

\title{
제품 개발과 디자인의 성공 사례
}

Hyong Jae Rhee

Gill Sang Ahn

Follow this and additional works at: https://amj.kma.re.kr/journal

Part of the Marketing Commons

\section{Recommended Citation}

Rhee, Hyong Jae and Ahn, Gill Sang (2002) "제품 개발 과 디 자인 의 성 공 사례," Asia Marketing Journal: Vol. 4 : Iss. 3 , Article 5.

Available at: https://doi.org/10.53728/2765-6500.1092

This Article is brought to you for free and open access by Asia Marketing Journal. It has been accepted for inclusion in Asia Marketing Journal by an authorized editor of Asia Marketing Journal. 


\title{
제품 개발과 디자인의 성공 사례 \\ :현대자동차 싼타페*
}

\section{A Case Study on Successful Product Development and Design :Hyundai Santa Fe}

\author{
이형재 (국민대학교 경영학부 조교수) \\ rheeh@kookmin.ac.kr
}

안길상(충북대학교 경영학부 교수)

ahn2334@trut chungbuk. ac.kr

경쟁이 치열한 글로벌 시장에서 우리나라 기업이 국제적인 경쟁우위 확보가 필수적인 세 계 경제환경이다. 고객의 요구를 선행적으로 파악하고 상품개발과 디자인에서 고객만족을 달성한 현대 자동차의 싼타페 사례를 분석한다. 퓨전 SUV 싼타페의 성공 요인은 크게 두 가 지로 볼 수 있다. 첫째, 소비자의 요구를 선행적으로 반영하여 안전성과 품질 면에서 뛰어 난 성능을 가진 제품을 개발한 것이다. 둘째, 미국 현지주도의 디자인 개발로 세단을 능가 할 수 있는 세련된 디자인과 알맞은 차체 사이즈로 글로벌 시장에서 소비자의 요구률 충족 시킨 것이다. 아울러 향후 제품 포지셔넝에 관한 전략적 방향을 분석한다.

- 사례접수: 02. 09 게재확정: 02. 10 


\section{1. 서론}

글로벌 시장에서 여러 국가의 많은 기업의 상품들이 경쟁하는 현실에서 기업의 경쟁력은 생존과 성공의 열쇠이다. 나아가 국가경제에 있어서도 세계 시장을 선도할 수 있는 한국 상 품은 지대한 관심사가 아늘 수 없다. 기업의 경쟁력은 근본적으로 상품이 얼마나 고객의 요 구를 선행적으로(proactively) 정확히 만족시키느냐 하는 것에 달려 있다고 할 수 있다. 자 동차 산업에서 이러한 기본원리에 충실한 대표적인 사례가 ' 현대 자동차의 싼타페' 라고 생각된다. 다음의 현대 싼타페 사례를 통해 상품개발과 디자인의 중요성을 강조하고자 한다.

\section{2. 시장조사를 통한 소비자 요구파악}

\section{1 새로운 SUV 차량에 관한 소비자 요구}

레저용 차량인 RV(Recreational Vehicle)에 관하여 1999년도에 수요동향에 관한 조사를 한 결과 다음과 같은 소비자의 의견을 들을 수 있었다. 스포츠 유틸리터 차량인 SUV(Sports Utility Vehicle)를 보유하고 있는 소비자중 $66 \%$ 가 차종의 선택의 폭이 좁다는 불만을 가지 고 있었다. 그리고 SUV 보유자중 $30 \%$ 는 4 륜 구동인 $4 W D$ 를 이용하지 않고 있었고, 2 륜 구동 을 선호하는 수요자의 비율도 $52 \%$ 로 나왔다.

중형 숭용차를 보유하고 있는 소비자들은 SUV에 대한 관심이 높지만 기존 SUV 차량의 승 차감이 줗지 않고 주행할 때 소음이 커서 SUV 구매를 주저하고 있었다. 기존 RV를 보유한 소비자들은 숭차감이 좋은 SUV를 요구하고 있었다. 고객들은 차량을 선택할 때 여전히 안전 을 최우선시 하는 경향이 있다. SUV 소비자들은 $4 \mathrm{WD}$ 의 사용비율이 낮으나 $4 \mathrm{WD}$ 의 수요가 높 을 것으로 예상되었다. 기존 SUV 보유자들은 차종 선택의 폭이 좁고 기존 모델에 식상해 있 어 다양하고 스타일이 떠어난 구색울 원하고 있었다.

\section{2 시장상황}

국내 자동차 시장은 1999년도에 IMF의 영향에서 빠르게 회복하고 있었다. RV 시장의 비중 이 전체 자동차 시장의 $21 \%$ 로 성장하였으며 SUV 시장도 10 만대 수준으로 크게 성장하고 있 었다.

세계 시장상황은 점차 다양화되는 소비자의 쇼구를 반영하기 위하여 box 타입의 정통형 SUV에서, SUV의 고유한 장점을 유지하면서 새로운 차종의 장점이 결합된 cross-over 형 SUV 로 옮겨가는 추세이다. 북미 시장에서는 SUV 시장이 지속적으로 성장할 것으로 예상되었고 소형 SUV 시장의 급격한 확대 가능성이 높았다. 서유럽 시장에서는 숭용차 시장이 지속적으 로 증가할 것으로 보였으며, 디젤엔진 차량의 시장점유율 비율이 확대될 것으로 예상 되었 다. 


\section{3. 싼타페 STP 전략}

\section{1 표적시장 선정}

싼타페의 1차 표적시장으로 28-39세의 남성올 선정하였다. 이들은 자영업 또는 전문직이 나 사무직에 종사하며 소득수준은 월 250-300만원 이다. 2차 표적시장으로 선정한 집단은 40-45세의 남성인데 이들은 자영업과 서비스직 또는 사무관리직에 종사하며 소득은 월 300 만원 이상의 수준이다. 이들 가운데 승용차를 보유하고 있는 소비자는 안전성의 요구를 추 구하고 있으며 RV를 보유하고 있는 소비자는 숭차감과 엔진의 정숙성의 개선을 희구하고 있 었다. 이러한 표적시장의 소비자들은 4 륜 구동의 디젤 또는 LPG 엔진의 SUV률 원하고 있었 으며 레저용으로 뿐만 아니라 도심 속에서 출퇴근에도 어울리는 디자인올 희구하고 있었다.

\section{2 포지셔닝}

표적시장의 요구를 분석하여 싼타페를 숭용차와 RV의 장점을 결합한 cross-over SUV의 대 표브랜드로서의 감성적, 총합적 가치를 개발하여 레저용 뿐 아니라 도심속에서의 출퇴근용 으로도 적합한 $0 \mathrm{n}-\mathrm{Road}$ 형 차량으로서 위상을 정립하였다.

<그림 1. SUV 지각도>

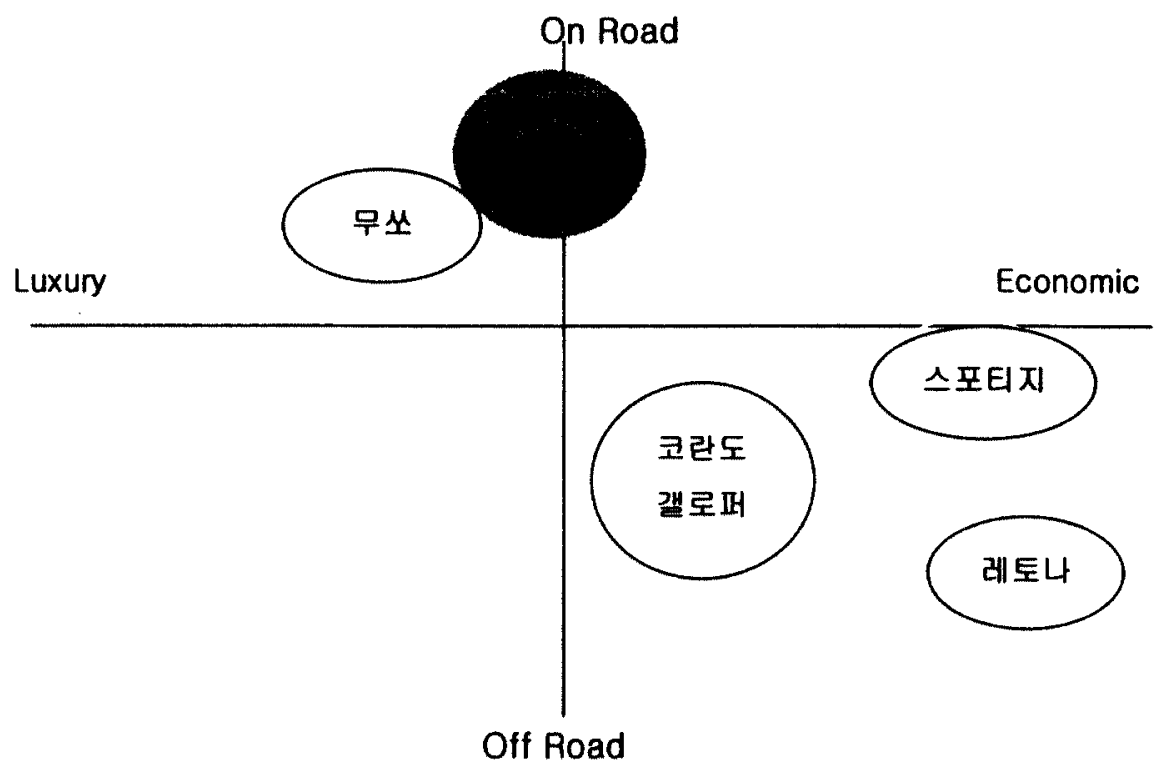

세계 자동차 시장의 흐름이 차종간의 장점을 결합한 fusion car 시대로 진입하고 있다. 싼타페를 수출전략형으로 개발하여 세계적인 수준의 디자인, 기술력, 품질을 갖춘 선도적인 
제품으로 개발한다. 그리하여 글로벌 브랜드로서 신뢰도를 제고하고 싼타페률 기회로 전 차 종으로 품질수준의 업그레이드를 도모하는 파급효과룰 기대한다.

\section{3 브랜드명 결정}

Santa Fe는 미국 뉴멕시코주의 주도로서 록키 산맥 남쪽 고지대의 고대 푸에블로 인디언 거주 지역이다. 이 곳온 레저문화가 발달한 관광의 중심지이다. 싼타페는 갈수록 더 많은 소비자가 관심을 기울이는 레저에 적합하다는 이미지를 부각시키면서 도심의 분위기률 내포 하고 있다.

\section{4. 신제품 및 디자인 개발}

\section{1 개발방향}

싼타페는 숭용차, SUV 그리고 다목적 차량(Multi-Purpose Vehicle)의 장점이 결합된 cross-over 형 차량으로 개발방향이 결정되었다. 다음의 네 가지 방향이 주요한 개발방향이 다.

첫째, 차체에 관해서는 새로운 플랫폼인 빌트 인 프레임으로서, 험로에서 주파성을 높이 고 승차감을 개선하고 안전성을 추구한다. 둘째, 승용형 디젤엔진을 채택하여 동력성능과 정숙성을 개선하고 연비를 꿀어올림으로써 경제성을 추구한다. 셋째, 독립현가 서스펜션으 로 승차감과 조종 안전성을 제고한다. 넷째, 최적의 package로 시계성을 확보하고 세련된 스타일의 디자인으로 출퇴근용과 레저용의 다목적성올 보유한다.

\section{2 엔진 테크놀로지}

싼타페 앤진으로서 디젤 2.0 앤진을 도입하여 출력이 뛰어나고 연비를 개선하였다. CRDi(Common Rail Direct injection) 엔진으로 기존의 동급 디젤엔진과 대비하여 출력을 약 $24 \%$ 향상시키고 연비는 약 $15 \%$ 높였으며 소음, 진동 및 배기가스 저감 효과를 가져왔다. 경쟁 차량에 비해 배기량은 줄이고 엔진의 출력과 연비를 높인 우수한 엔진을 탑재하였다.

<표 1. 엔진 성능 비교>

\begin{tabular}{|l|l|l|l|}
\hline \multirow{2}{*}{ 구 분 } & 싼타페 & 무쏘 \\
\cline { 2 - 4 } & 디젤 2.02WD M/T & 디젤 2.0 4WD M/T & 디잴 2.3 4 WD M/T \\
\hline 배기량 $(\mathrm{cc})$ & 1.991 & 1.997 & 2.299 \\
\hline 최고출력 $(\mathrm{ps} / \mathrm{rpm})$ & $115 / 4,000$ & $115 / 4,000$ & $101 / 4,000$ \\
\hline 최대토오크 $(\mathrm{kg} . \mathrm{m} / \mathrm{rpm})$ & $26.5 / 2,000$ & $26.5 / 2,000$ & $21.5 / 2,400$ \\
\hline 연비 $(\mathrm{km} / \mathrm{t})$ & 13.4 & 12.8 & 11.7 \\
\hline
\end{tabular}




\section{3 자동변속기와 현가장치}

자동변속기로는 H-MATIC 자동변속기를 개발항여 운전의 용이성올 높이고 주행 안전성과 변속 응답성을 제고하여 소비자가 운전의 재미를 느낄 수 있도록 했다.

현가 장치(suspension)로서 맥퍼슨 스트러트식 전륜 써스펜션을 도입하여 조향 안전성과 롤링 제어성능 향상을 도모했다. 그리고 후륜 써스펜션으로서 더블 위시본 타입을 채택하여 안락한 숭차감과 우수한 조종 안전성을 확보했다. 이로써 싼타페는 국내 유일의 후륜 독립 현가 써스펜선 SUV가 된다.

\section{4 구동시스템}

싼타페는 고속선희가 가능한 이상적인 구동 시스템을 갖추고 있다. DDU(Double Differential Unit)의 작동에 의해 전/후륜에 각각 $60 \% / 40 \%$ 의 구동력을 배분한다. 비스커스 커플링으로 고점도 유체 커플링이 구동력을 전/후륜에 최적상태로 배분하여 구동력을 향상 시키고, 전/후륜의 회전차이가 발생되는 눈길, 빗길 등 미끄러운 노면에서 최적의 구동력을 발휘한다. 파트 타임 4WD가 tight corner braking(차량 선회시 전후륜간 회전반경 불일치로 인한 전후륜 구동계의 간섭현상) 이라는 단점이 있는 반면, 싼타페는 풀 타임 $4 \mathrm{WD}$ 을 채택함 으로써 이러한 단점을 제거하고 운전 편의성을 증대하였다.

<표 2. 고속선회가 가능한 이상적인 구동시스템 >

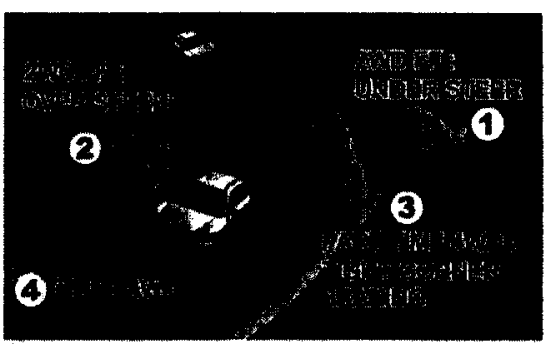

\begin{tabular}{|c|c|c|}
\hline & 구동 방식 & 단 점 \\
\hline (1) & $2 \mathrm{WD} \mathrm{F} \mathrm{F}$ & UNDER STEER \\
\hline (2) & $2 \mathrm{WDFR}$ & OVER STEER \\
\hline (3) & 파트 타임 4WD & " TIGHT CORNER BRAKING \\
\hline (4) & 풀 타임 4WD & - \\
\hline
\end{tabular}

\section{5 소음 차단성}

각 필라부 단면 중대 및 발포패드, 폴리 우레탄 스폰지를 적용하여 엔진의 소음을 제거하 였다. 팬더 판넬에 차음재를 적용하여 엔진 투과음 및 wind noise 차단하였다. 샌드위치 방 식의 대쉬 및 인슐레이션 패드 적용으로 엔진 투과음을 차단하였다

\section{6 실내 인테리어 및 공간}

운전자 중심의 랩 어라운드 스타일을 도입하여 luxuary-sporty 이미지를 추구했다. 최적 의 차체 사이즈로 운전 편의성을 제공하였고 차체 대비 폭 넓은 실내공간을 제공하였다. 싼 
타페 보유자의 차량크기에 대한 긍정(만족)도가 가장 촢았고(50\% 이상), SUV를 처음 구입 한 사람보다는 대체 구입자가 좀더 큰 차체를 원하고 있었다. 싼타페는 적절한 차체 사이즈 (코란도 보다는 크며 무쏘/테라칸 보다는 작음)로 신규 구입자와 대체 구입자의 얂측에서 수요를 견인할 것으로 예상되었다. 그리고 mini-van을 능가하는 다양한 seat variation으로 실내공간을 다용도로 효율적인 사용이 가능하게 하였다.

\section{7 디자인 개발}

싼타페의 디자인 개발은 글로벌 시장을 지향하였다. 세계 자동차 시장을 대표할 수 있는 미국 소비자의 SUV에 관한 철저한 의식조사를 통하여 핵심 디자인 컨셉을 잡았다. 미국 캘 리포니아주의 Cal-Tech 디자인 연구소에 의뢰하여 인테리어는 western style로 하고 외부 디자인은 out-door 이미지를 강하게 어필할 수 있도록 하되 승용차를 능가하는 세련된 디자 인과 적절한 차체 사이즈를 결정하였다. 이로써 SUV를 제2의 차로서 디자인이 우수한 SUV(" look-at-me" style)롤 선호하는 소비자들의 요구를 충족하도록 하였다.

\section{5. 광고와 판매 촉진 전략}

\section{1 런칭광고 컨셉}

싼타페를 시장에 런칭하기 위하여 시장상황을 조사한 결과 다음과 같았다. LPG에 대한 가 격인상으로 RV 시장의 성장률이 감소하고 있었고, SUN 시장에서는 현대가 열세의 위치에 있 었다. 런칭 광고의 과제는 SUV 시장에서 경쟁 브랜드인 쌍용의 코란도와 무쏘를 공략하면서, 동시에 자사의 트라제와의 상호 간섭 내지 충돌현상 을 최소화하는 것이다.

2000 년 상반기에 런칭 광고의 전략은 먼저 목표 소비자집단의 프로필은 20대 중반-30대 후반의 남성으로 전문직/사무직/관리직에 근무하는 월 250 만원 이상의 소득층으로서, 주말 올 이용하여 레저와 스포츠를 추구하며 외관을 중시하는 과시형이며, 탈세단 성향이고 활동 적이며 스포티한 디자인을 선호하는 개성중시형이다. 광고 컨셉은 도시와 자연의 fusion, new \& upper style의 도시형 SUV로 잡았다. 브랜드 슬로건은' 퓨전카, 싼타페 (도시/선망/ 낭만/환상/드라이빙....... )' 으로 결정했다

\section{2 런칭 광고 매체 전략}

런칭 광고는 주로 TV를 통하여 시장진입 3 개월 이전인 2000년 6월부터 집중적으로 실행되 었다. TV CF와 연동하여 신문, 라디오와 잡지를 통해 런칭 광고률 했다. 기타 옥외광고는 신촌과 강남 등 5 개소의 대형 전광 LED에 실행하였다. 4 대 매체와 기타 광고의 총 예산은 약 83 억원이 집행되었다. 


\section{3 싼타페 유지 $\mathrm{CF}$ 기획 방향}

경쟁사 신차의 런칭 전략에 대응하여 cross-over SUV 이미지를 선점하고 강화하는 커뮤니 케이션 전략이 펄요하다. 싼타페는 Cross-over(도시형) SUV의 대표 브랜드로서, SUV, 미니 밴, 세단시장 이외에 존재하는 제 3 의 시장요구를 충족시킨다는 것올 강조한다. 자사의 다 른 계층의 브랜드인 렉스턴, 쏘렌토가 출시됨에 따라 도시형 SUV 1위 브랜드로서 이미지를 강화시키는 것을 목표로 한다. 싼타페의 감성적, 촣합적 매력을 이미지화 하여 $\mathrm{CF}$ 의 핵심 카피를 "도시의 매혹, 싼타페 '또 다른 길을 가는 즐거움" "으로 잡는다.

<표 3. 런칭광고 매체 집행부문 요약(2000년)>

(단워 : 백만원)

\begin{tabular}{|c|c|c|c|c|c|c|c|}
\hline & \multirow{2}{*}{ 매체 } & \multirow{2}{*}{ 운영기간 } & \multirow{2}{*}{ 집 형예산 } & \multicolumn{4}{|c|}{ 내 역 } \\
\hline & & & & TRPS & Feach +1 & Ave. Freq. & 내용 \\
\hline \multirow{7}{*}{$\begin{array}{c}4 \\
\text { 대 } \\
\text { 애 } \\
\text { 채 }\end{array}$} & TV & $6-9$ 월 & 3.313 & 2,202 & $97 \%$ & 22.7 & 런칭 $\mathrm{CF}$ \\
\hline & \multirow{4}{*}{ 신문 } & 6월 & 680 & 114 & $62 \%$ & 1.8 & 런칭 1차 TV 연동 \\
\hline & & 7월 & 764 & 113 & $60 \%$ & 1.9 & 런칭 2차 TV 연동 \\
\hline & & 8월 & 869 & 106 & $51 \%$ & 2.1 & 고ㄷㅣㅣ자인 대뽛령상 수상 \\
\hline & & 11월 & 648 & 86 & $55 \%$ & 1.6 & 응용형 듸젤 런칭 \\
\hline & 라디오 & $\begin{array}{l}6-10 \text { 월 } \\
11-12 \text { 월 }\end{array}$ & 811 & \multicolumn{4}{|c|}{ 런칭 CF 연동 / 승용형 디젤 런칭 } \\
\hline & 잡지 & $6 \sim 9$ 원 & 81 & \multicolumn{4}{|c|}{ 시사지 잋 자둥차 전문지 집중 집행 } \\
\hline \multirow{3}{*}{$\begin{array}{l}\text { 기 } \\
\text { 타 }\end{array}$} & 옥외광고 & $7-12$ 월 & 597 & \multicolumn{4}{|c|}{ 신츤, 강남 전광 LED 광고외 5 개소 집행 (LED 광고 워주) } \\
\hline & 인쇄몰 & 6 월 & 381 & \multicolumn{4}{|c|}{ 런칭 및 정기 인쇄물 } \\
\hline & POP & 6 월 & 106 & \multicolumn{4}{|c|}{ 런칭 관련 전정소 배포 POP } \\
\hline \multicolumn{3}{|c|}{ 합 계 } & 8,250 & & & & \\
\hline
\end{tabular}

\section{자료원}

1. 4대애체 집행예산 : KADD
2. 기타매체 집행예산 : HMC 내부자료 
<그립 2. 유지 CF 기혁을 위한 SWOT 분석>

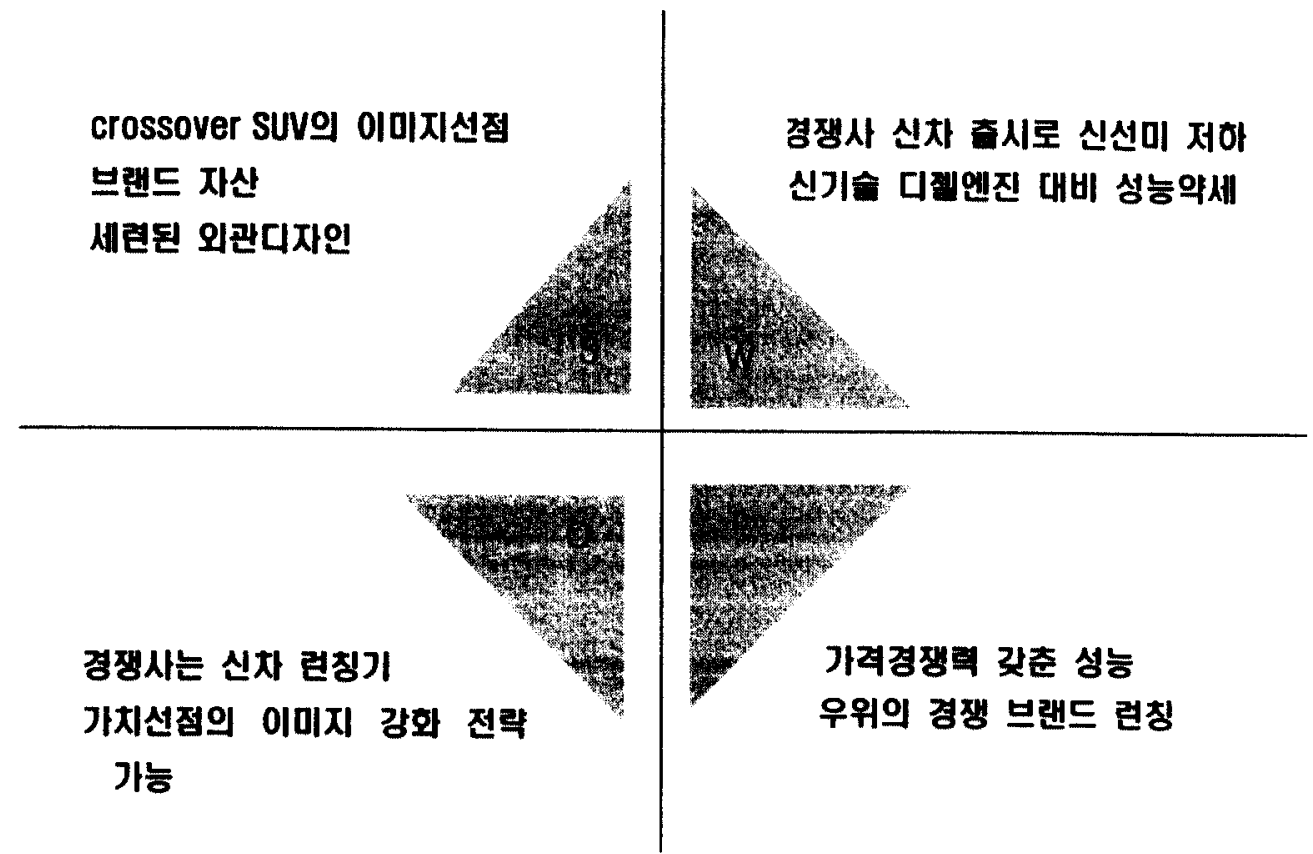

SWOT 분석을 통하여 살펴보면 강점으로는 cross-over 이미지률 선점하고 세련된 외관 디 자인을 가지고 있으며 판매성과와 각종 국내외 수상경력으로 브랜드 자산올 형성하고 있다. 약점으로는 경쟁사도 신차롤 출시하여 신선미가 약화되고 신기술의 디젤엔진(2.5 CRDi)에 대비하여 성능이 약세에 있다는 것이다. 기회로서 경쟁사는 신차의 런칭기이기 때문에 가치 선점의 이미지 강화전략이 가능하다. 위협적인 요소는 성능이 높고 가격경쟁력을 갖춘 디젤 엔진이 장착한 경쟁차가 런칭될 가능성이 있다는 것이다.

\section{4 홍보 전략}

출입 기자들에게 시숭 차량을 대폭 지원하고 시숭기 게재를 유도했다. 언론사의 구전효과 를 극대화하기 위하여, 언론사의 경제부/산업부는 물론 타부서의 기자/직원의 요청에도 시 숭 차량올 적극 지원했다. 완성도 높은 기흭 기사를 작성하여 줌으로써 기사작성의 편의성 을 제공했다. 연구개발에 관한 자료 $\mathrm{HTi}$ 디젤엔진 개발, 2000 년 11월; 하이브리드/미국 충 돌시험, 2001년 3월; 전기차 2001년 7월)와 수상 자료(산업 디자인상, 2000년 8월; 미국 소 비자 만족 1위, 2001년 5월; 디자인 경영대상, 2001년 11월)를 근거로 보도자료를 지속적으 로 개발하여 언론매체에 제공했다. 


\section{5 싼타페 판매촉진 전략}

제 1기(2000-2001년)에는 이미지 제고 전략을 추진했다. 성악가 파바로티의 공연에 고객 율 초청하고 신차 전시희 및 시승희룰 가졌다. 하계 휴양지의 고객을 집중 공략하여 구전 마케팅올 실시하였다. 설악 콘도 단지와 성우 콘도에 고객초청 행사와 드라이빙 체험 행사 롤 가졌다. 온라인과 오프라인 SUV 동호회률 통한 구전 마케팅도 실시하였다. 제 2기(2002 년 이후)에는 e-mail을 통한 판촉 마케팅을 강화한다. 공급지연에 따른 고객불만을 최소화 하기 위하여, 차량 인도지연에 관한 고객안내문을 발송하여 고객이탈을 방지하고, 선계약 선출고 시스템을 구축한다.

\section{6. 시장 성과}

\section{1 국내 시장성과}

국내 자동차 시장규모가 IMF 이전 수준까지 회복된 가운데, 상숭추세가 나타나고 있다. 자동차 시장 중 $\mathrm{RV}$ 시장이 급증하여 2002 년도에는 전체 시장의 30 \% 수준까지 점유할 것으로 예상된다.

RV 시장 중에서 minivan 등의 다목적용 차량인 MPV의 수요증가가 둔화되고 SUV 수요가 급 중하는 추세이다. SUV에 관한 국내법규에서 숭합차에서 승용차로 변경되고, $\mathrm{LPG}$ 의 가격이 인상되고 신기술인 디젤 SUV가 출시 되면서 RV 시장의 무게 중심이 SUV로 급격히 움직이고 있는 양태이다. 2000년 SUV 대 MPV의 비율이 30.7\% 대 69.3\%에서 2002년 전망치는 56.4\% 대 43.6\% 이다. SUV 시장에서 싼타페의 점유율은 $26 \%$ 이고 현대자동차가 $45.3 \%$ 점유율을 차지하 고 있으므로, 싼타페가 현대자동차 SUV의 $60 \%$ 를 점하고 있다.

국내 판매는 2000 년 2/4분기부터 탄력을 받아 크게 중가하고 있는데, 2002년 1월 판매실 적이 6,091 대이고 납기가 2.5 개월로 계약 미출고 분이 뼈르게 늘고 있다. 해외인 경우 2002 년 1 월 판매실적이 12,748 대이고 납기가 3 개월 이상이다

<그립 3. 국내 판매현황>

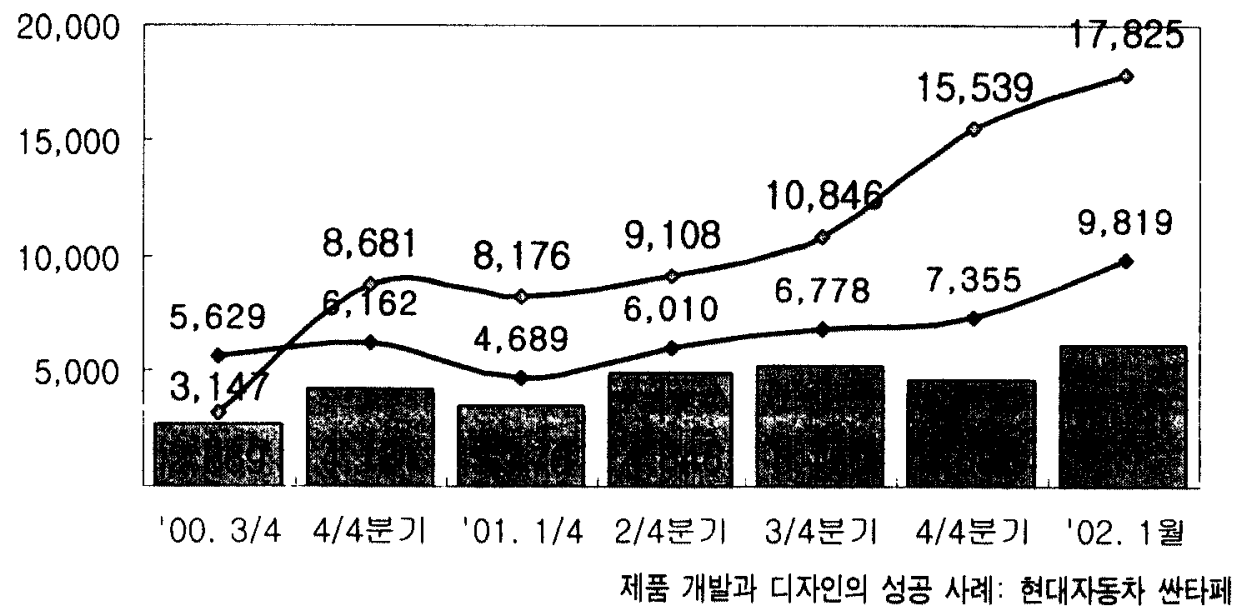




\section{2 해외 시장성과}

북미 시장의 경우에는 2000년 (9월 이후) 실적이 11,165 대이고, 2001 년 실적은 61,503 대로 성장하였다. 유럽시장도 2000년 (9월 이후) 실적이 917대이고 2001년 실적은 25,106 대로 크게 증가하였다.

미국 시장의 판매추이는 2000 년 9 월 시장 진입이후 빠르게 증가하고, 겨울과 초 봄에 수 요가 감소하는 계절적 효과가 발생하였으나, 이후 성장을 거듭하고 있다. 2001년도 실적은 56,017 대이고 2002 년 1월의 세그먼트 점유율은 6 에 달하였다.

<그림 4. 미국시장 판매추이>

\section{Santa Fe Sales Growth}

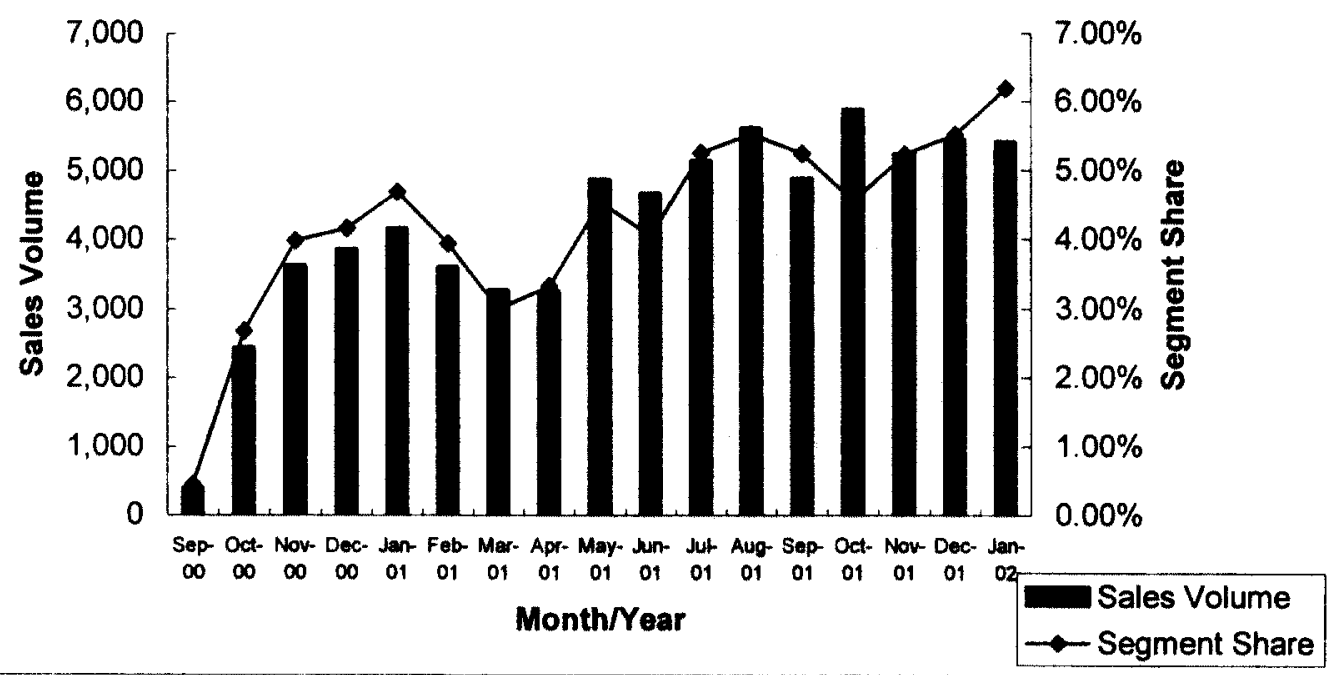

\section{7. 성공 요인과 향후 전략}

퓨전 SIF 싼타페의 성공 요인은 크게 두 가지로 볼 수 있다. 첫쩨, 소비자의 요구를 선행 적으로 반영하여 뛰어난 성능을 가진 제품올 개발한 것이다. $4 \mathrm{WD}$ 의 강한 내구성을 가진 구 동장치와 높은 파워의 $\mathrm{CRDi}$ 앤진올 장착했다. 숭차감은 중형 세단 수준으로 높이고 다용도 성으로 레저용와 출퇴근용으로 사용 기반을 넓혔고, SUV 본연의 다이나믹한 주행성능을 지 녔다. 안전성과 품질부문에서 미국시장에서 동급내 최고의 품질로서 인정을 받았다. 미국에 서 실시한 안전성 검사에서 FSST(five-star safety test) 수준을 획득하고, 40마일 충돌테 스트에서 소형 SUV 부문 중 1 위를 차지했다. 그리고 각종 자동차 전문기관(J.D. Power, 
AutoPacific, Strategic Vision 등)에서 호평올 받고 있다. 또 하나의 성공요인은 현지주도 의 디자인 개발이다. 미국 캘리포니아 Cal-Tech 디자인 연구소에 의뢰하여, 세계 자동차 시 장을 대변할 수 있는 미국 소비자의 SUV 의식울 철저히 조사하여, 세단울 능가할 수 있는 세련된 디자인과 알맞은 차체 사이즈로 소비자의 요구를 충족시킨 것이다.

향후 싼타패의 전략은 Cross-over SUV의 대표 브랜드로서 유형적 가치와 무형적 가치의 총합을 제고하고 글로벌 시장에서 소형 SUV의 리더 브랜드로서의 이미지를 강화해 나가야 한다. 자사의 상위(up-scale) 브랜드인 테라칸은 보다 고급화 시켜 최고의 성능 이미지를 강화하여, 상호 이미지 충돌을 방지하고 오히려 품질과 디자인 면에서 상호 보완적인 시너 지 효과를 거둘 수 있도록 해야 할 것이다.

<그림 5. 싼타페 향후 전략방향>

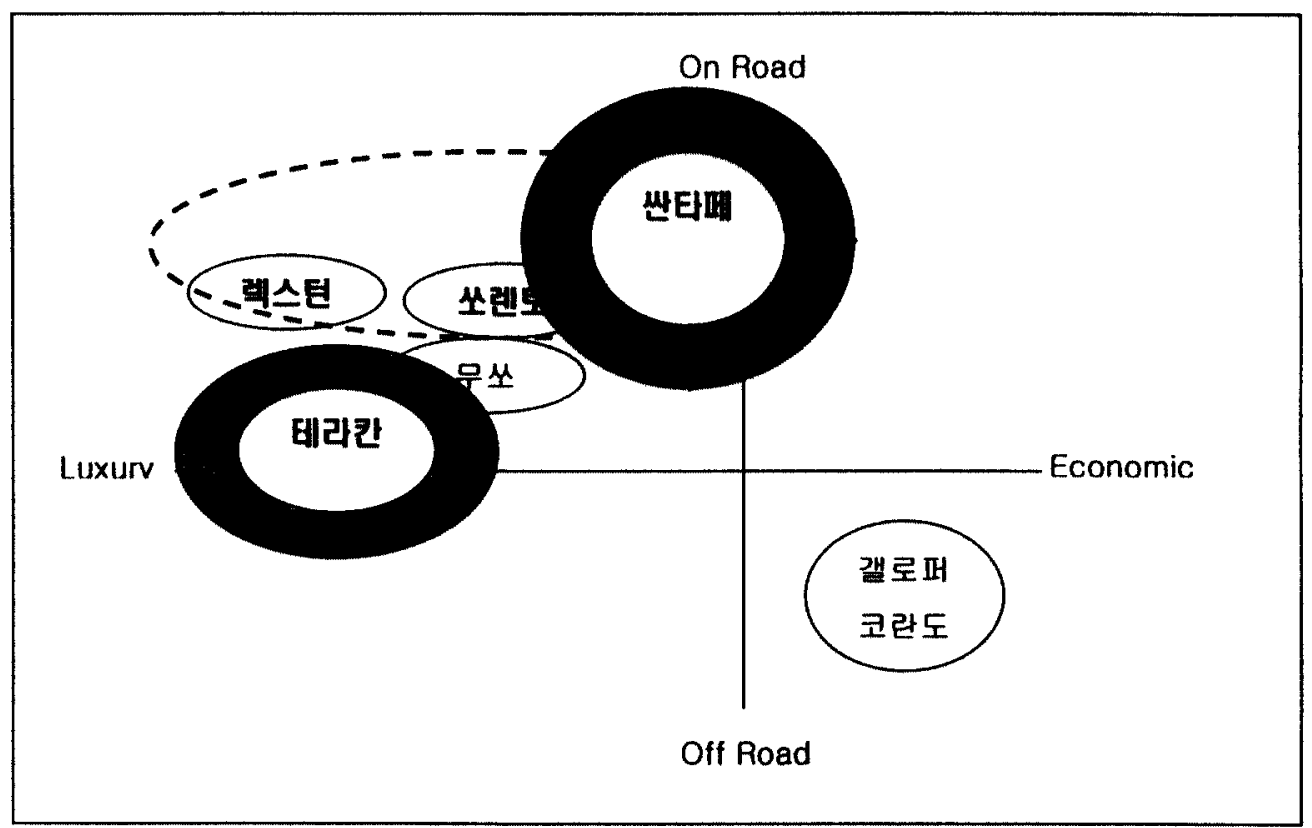

